\title{
Impact of Income on Households Patterns of Consumption of Street Vendors in Makassar City
}

\author{
Andi Samsir \\ Universitas Negeri Makassar \\ Makassar, Indonesia \\ Email: syamsir_fe03unm@yahoo.co.id
}

\author{
Muhammad Imam Ma'ruf \\ Universitas Negeri Makassar \\ Makassar, Indonesia
}

\author{
Rudi Salam \\ Universitas Negeri Makassar \\ Makassar, Indonesia \\ Email: rudisalam@unm.ac.id
}

\begin{abstract}
Economic growth of Makassar City which is above average of the national economic growth about 7-8 percent per year makes the city as one of the magnet not least for economic actors in the informal sector. The high velocity of money in public spaces does not want to be wasted by economic actors in this sector to profit by peddling their merchandise or services. Indeed, the amount of profit is available to be one of the attractiveness for urbanization in the city. Utilization of spaces such as sidewalks and shop stalls by street vendors in doing their business to become a familiar phenomenon in major cities such as Makassar. The lack of assets and the level of education owned by the business actors become them make the public space as the only alternative in doing the business and is the source of their household livelihood. The phenomenon of poverty in the community does not discourage their intention to keep trying despite having to deal with government officials even against the law. Government policies in tackling poverty still cannot reduce this spatial problem such as creating jobs in the formal sector or providing space (market) to maintain their minimum consumption. The high dependence on the income of street vendors in maintaining their consumption patterns make this sector occupied by a lot of people who are categorized as poor. Based on these problems, the problem questions in this research is; the first, how the influence of business income and other income on the pattern of household consumption of street vendors in the city of Makassar; the second, whether influence of the business income greater than other income so that it can change the pattern of household consumption of street vendors in Makassar. The research method used in this research is descriptive and explanatory method. To test and analyze the effect of business income and other income on household consumption of street hawkers in Makassar City using Keynes consumption function through multiple regression. The value of constant 3.867.020.062 indicates if the independent variable has a value of zero or not then the big spending household consumption in the city of Makassar accounted IDR 3.867.020.062. Based on the results of research shows that business income affects the pattern of household consumption of street vendors in Makassar. Meanwhile, Other income does not affect.
\end{abstract}

Keywords- business income, household consumption, street vendors

\section{INTRODUCTION}

The problem of poverty is still a phenomenon that cannot be separated from developing countries [1]. The phenomenon was intensified after it was found that a high and consistent growth rate from year to year was not necessarily followed by a decrease in poverty. Poverty alleviation is at the core of all development issues and a key development policy in many developing countries [2].
In Indonesia, the rate of economic growth that showed a positive trend after the crisis of 1997/98, where the average growth rate is about 6-7 percent per year, is very encouraging and places Indonesia as one of the countries with high growth rates for some decades. However, the growth has not been able to shift the position of Indonesia as a country with lower middle income category (the low-middle income country). In fact, based on data from the Central Bureau of Statistics inflation phenomena such as those caused by government policies to reduce fuel subsidy and basic electricity tariff are very susceptible to the increase of relative poverty in Indonesia.

The economic growth of Makassar is above the national economic growth average of 7-8 percent per year making the city as city as one of the magnet not least for economic actors in the informal sector. The high velocity of money in public spaces does not want to be wasted by economic actors in this sector to profit by peddling their merchandise or services. Indeed, the amount of profit is available to be one of the attractiveness for urbanization in the city. Utilization of spaces such as sidewalks and shop stalls by street vendors in doing their business to become a familiar phenomenon in major cities such as Makassar.

However, the economic motive of the street vendors gave birth to the spatial problems in Makassar. The transition of the function of public spaces to the aspect of the beauty of the city is the main reason for the government to evict and relocate that can have a direct impact on the income of the street vendors. As a form of small-scale economic activity that produces and distributes goods and services, these public spaces are their primary markets to interact intensively and massively with consumers because of the zero explicit costs required to attract consumers into market. However, the spatial policy of Makassar City becomes an obstacle for them to be able to run their business which resulted in the loss of some even the entire business revenue.

The lack of assets and the level of education owned by the business actors makes them make the public space as the only alternative in doing the business and is the source of their household livelihood. The existence of the phenomenon of poverty in the community does not decrease their intention to keep trying despite having to deal with government officials even against the law. Government policies in poverty reduction are still considered not able to reduce the spatial problems such as creating employment in the formal sector or providing a representative (market) space to maintain their minimum consumption. 
.... .... z. zconomic growth in Makassar is responded by the government by providing supporting facilities and infrastructure to keep the trend of economic growth still positive. Therefore, it is often found that the city government policy is considered not pro poor such as street vendors in several roads in Makassar City, such as which occurred on street vendors around Jalan Andi Pangeran Petta Rani during the year 2008-2010. As a business center, the availability of space to run the business is the main capital for business actors, including in the informal sector. However, the amount of costs incurred for the utilization of space is causing most business actors in the sector to make public spaces as substitution of space that has been provided by the government.

The high dependence on the income of street vendors in maintaining their consumption patterns make this sector a lot of people who are categorized as poor. Their efforts to live above the poverty line can be partially answered by exploiting these public spaces even though they are always haunted by government eviction policies. Pursuant to result of research in Regency of Salahtiga show that average of business income of street vendors in the area is 100-500 thousand rupiah per day [3]. Compared to the city of Makassar with the status as a metropolitan city with a relatively higher rate of economic growth is very possible to earn their average income is at a greater number again.

Based on these problems, the problem questions in this research is; the first, how the influence of business income and other income on the pattern of household consumption of street vendors in Makassar; the second, whether influence of the business income greater than other income so that it can change the pattern of household consumption of street vendors in Makassar city. According to the background of the problem, the purpose of this study is to see how the effect of business income and other income on household consumption on street vendors in Makassar.

\section{METHOD}

Based on the research problems presented earlier, the basic method used in this research is descriptive and explanatory method. The kinds of data in this study based on the time dimension, namely cross-section data based on research objectives. The type of data used in this study is the primary data that obtained by direct observation in the research location and conducting interviews to household respondents. The location of research is determined purposively based on region that spread of place of business street vendors in Makassar, that is about 14 sub districts [4]. Furthermore, the sample is taken by using proportional random sampling technique and the determination of sample size used Slovin formula.

To test and analyze the effect of business income and other income on household consumption of street Vendors in Makassar use Keynes consumption function through multiple regressions as follows:

$$
C R T=\beta_{0}+\beta_{1} P U+\beta_{2} P L+\mu_{1}
$$

$$
\begin{array}{ll}
\text { Explanations: } & \\
\text { CRT } & : \text { Household consumption (IDR) } \\
\beta_{0} & : \text { intercept/konstanta } \\
\beta_{1}, \ldots, \beta_{2}: \text { koefisien regresi of Independent variable } \\
\text { PU } & : \text { Business Income (IDR) } \\
\text { PL } & : \text { Others Income (IDR) } \\
\mu_{1} & : \text { disturbance error }
\end{array}
$$

Hypothesis testing of the regression coefficients is jointly used F-test and t-test with a certain level of confidence about
90 percent or level of significance about 10 percent. To test the feasibility of the model (BLUE) using the classical assumption test [5]. This study uses VIF in multicolinearity testing which is found in statistical program for service solution (SPSS) statistics17. Furthermore, in this research the method used is park test to detect heterokedastisitas.

\section{RESULTS}

The influence of business income and others income on the pattern of household consumption of street vendors in Makassar use multiple regression analysis model and classical assumption test, that is multicolinearity and heteroscedasticity. They have a positive correlation sign which means that any increase in business income will increase followed by an increase in household consumption patterns of street vendors in Makassar. It is also the same case with other income on the pattern of household consumption of street vendors in the city of Makassar. It is presented in Table 1:

Table 1 Analysis of the effect of business income and other income on consumption patterns of street vendors in Makassar

\begin{tabular}{lccccr}
\hline $\begin{array}{l}\text { Independent } \\
\text { Variable }\end{array}$ & TH & $\beta$ & $\mathrm{t}_{\text {calculate }}$ & Sig & VIF \\
\hline Business & + & $0,089^{*}$ & 1,652 & 0,100 & 1,004 \\
Income & + & $-0,015$ & $-0,233$ & 0,816 & 1,004 \\
Others Income & & & & & $2.519 .389,37$ \\
\hline Konstanta & & & 0,008 \\
\hline Adjusted $\mathrm{R}^{2}$ & & & 1,374 \\
\hline $\mathrm{F}_{\text {calculate }}$ & & & 3,940 \\
\hline $\mathrm{F}_{\text {standar }}$ & & & 100 \\
\hline $\mathrm{N}$ & & & 1,000 \\
\hline Park test & & & \\
\hline
\end{tabular}

Source: Results of Processing Data, 2017

Explanation

$*)$ : Significance level on $10 \%(0,10)$
$n s:$ non significant
$T H:$ sign of expectation

According to the analysis used, then obtained the regression equation as follows:

$C R T=2.519 .389,37+0,089 P U+\mu_{1} \ldots \ldots \ldots \ldots . .(2)$

The statistical tests performed were $\mathrm{F}$ test and $\mathrm{t}$ test. The $F$ test is used to test the effect of simultaneously independent variable to the dependent variable. From result of $F$ test show that the value of $F_{\text {calculate }}$ is about 1,374 , while value of $F_{\text {standar }}$ is about 3,940. Because of value of $F_{\text {calculate }}>F_{\text {standar }}$ means simultaneously effect of independent variables no significant on the dependent variable.

Furthermore, $t$ test is used to test whether the independent variables partially significant effect on the dependent variable. The result of partial test shows that the variable of business income has significance value equal to 0,100 or greater than 10 percent which means the business income influences the consumption pattern of street vendor in Makassar. Meanwhile, other income has a significance value of 0.816 or smaller than 10 percent which means other 


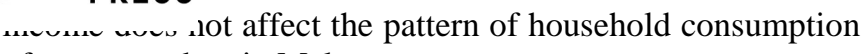
of street vendors in Makassar.

To know the contribution of independent variable to dependent variable is used measure of accuracy of coefficient model of determination adjusted R2. From the calculation results using SPSS, coefficient of determination adjusted R2 obtained by 0.008 or 0.8 percent. From these results indicate that the independent variables in the model presented can explain by 0.8 percent of the rise and fall of the dependent variable while the rest of 99.2 percent is determined by other variables outside the model. However, the significance test (F-test) does not show any independent variable influence simultaneously to the dependent variable so that the value of adjusted R2 has no meaning.

Multicollinearity test which aims to test whether in the regression model that formed there is a high or perfect correlation between independent variables or not. If in the regression model formed there is a high or perfect correlation between independent variables, then the regression model is expressed to contain symptoms multicollinearity. From multicollinearity test result using Variance Inflaction Factor (VIF) method showed no multicollinearity in independent variable because VIF value of both variables is smaller than 10.

Heterokesdisitas test using Park Test method obtained the value of each independent variable to the consumption pattern of 1,000. This shows that there is no heterokesdisitas. The value of constant of 2,519,389.37 indicates that if the independent variable has a value of zero or neglected then the large consumption of household consumption of street vendors in Makassar amounted to IDR 2,519,389.37. Meanwhile, to see the influence of each independent variable to the dependent variable based on $t$ test result (student $t$ test) in this research is:

\section{A. Effect of Business Income on Consumption Pattern of street vendors household in Makassar}

Value of variable coefficient business income amounted to 0.089 which means that every 1 percent increase in business income, it will increase consumption by 0.089 percent. This shows that the effect of business income of 0.089 percent on the pattern of household consumption of street vendors in Makassar.

The results of this study are in accordance with the theory proposed by Thomas to see the working hypothesis of Keynes's consumption theory at Ekiti State of Negeria shows that income has a significant effect on consumption expenditure at Ekiti State [6]. Meanwhile, found that income variables have an important impact on household food expenditure in Greece [7]. In empirical analysis, this study also shows a strong relationship between the two variables, where the relationship is in accordance with the law of Engle.

\section{B. Effect of Others Income on Consumption Pattern of street vendors household in Makassar}

Based on the results of statistical tests (t-test) showed that other income does not affect the pattern of household consumption of street vendors in Makassar. Whatever other income earned will not affect their consumption patterns. The results of this study are not in accordance with the theory proposed by Keynesian and Phillips in the study found that individual consumption will be determined by income [8].

Different things are also shown by the results of research Thomas (2013) to see the working hypothesis consumption theory of Keynes in Ekiti State of Negeria showed that opinions have a significant effect on consumption expenditure in Ekiti State [9]. Meanwhile, Kostakis (2012) found that income variables have an important impact on household food expenditure in Greece [10]. In empirical analysis, this study also shows a strong relationship between the two variables, where the relationship is in accordance with the law of Engle.

\section{CONCLUSION}

Based on the results of research shows that business income affects the pattern of household consumption of street vendors in Makassar. Meanwhile, Other income does not affect. In this study found a variety of things that are considered important to be given advice to; the first, The next researcher to be able to conduct more in-depth research with various approaches in order to reveal the problems that exist in the household of street vendors in Makassar; the second, the Government of Makassar is expected to take a policy that stands on the interests of marginal communities especially street vendors in Makassar; the third, Related parties, both government and non-government institutions, to carry out empowerment activities for street hawkers in Makassar City in relation to business strengthening and capacity building.

\section{REFERENCES}

[1] D. W. Soskice and P. A. Hall, Varieties of capitalism: The institutional foundations of comparative advantage. Oxford University Press Oxford, 2001.

[2] M. Woolcock and D. Narayan, "Social capital: Implications for development theory, research, and policy," world bank Res. Obs., vol. 15, no. 2, pp. 225-249, 2000

[3] B. C. Sekaran Campus and S. Gunungpati, "Legal Policies Related to the Provision Of Open Green Spaces in Town Semarang."

[4] A. A. Patunru, N. McCulloch, and C. Von Luebke, "A tale of two cities: the political economy of local investment climate in Solo and Manado, Indonesia," IDS Work. Pap., vol. 2009, no. 338, pp. 1-43, 2009.

[5] D. N. Gujarati and D. Porter, "Basic Econometrics Mc Graw-Hill International Edition,” 2009.

[6] A. Thomas, "Determinants of Consumption Expenditure in Ekiti State," 2013.

[7] M. L. Axelson, "The impact of culture on foodrelated behavior," Аnnu. Rev. Nutr., vol. 6, no. 1, pp. 345-363, 1986.

[8] S. Mazumder, "The new Keynesian Phillips curve and the cyclicality of marginal cost," J. Macroecon., vol. 32, no. 3, pp. 747-765, 2010.

[9] I. A. Ilori and M. O. Ajiboye, "The Impact of Health Expenditure on the Growth of the Nigerian Economy: The ARDL Approach," Int. J. Econ. Commer. Manag. United Kingdom, vol. 3, no. 12, 2015.

[10] I. Kostakis, "Households' saving behavior in Greece corresponding countermeasures in financial crisis," Int. J. Econ. Pract. Theor., vol. 2, no. 4, pp. 253-265, 2012 . 